\title{
Biooxidation of Copper Sulfide Minerals
}

\author{
Yu. Elkina ${ }^{1,2(\bowtie)}$, E. Melnikova ${ }^{2}$, V. Melamud ${ }^{2}$, and A. Bulaev ${ }^{1,2}$ \\ ${ }^{1}$ Faculty of Biology, Lomonosov Moscow State University, Moscow, Russia \\ yollkina@mail.ru \\ ${ }^{2}$ Research Center of Biotechnology RAS, Moscow, Russia
}

\begin{abstract}
The effects of temperature and the presence of $\mathrm{NaCl}$ on bioleaching of chalcopyrite, enargite, and tennantite were studied. Rate of copper extraction from all minerals depended on temperature and was the highest at $45-50{ }^{\circ} \mathrm{C}$. $\mathrm{NaCl}$ addition increased rate of copper extraction from chalcopyrite but led to the decrease in copper extraction from enargite and tennantite.
\end{abstract}

Keywords: Bioleaching $\cdot$ Chalcopyrite $\cdot$ Enargite $\cdot$ Tennantite $\cdot$ Acidophilic microorganisms

\section{Introduction}

Copper and zinc are mainly extracted from sulfide ores using pyrometallurgical techniques. Pyrometallurgical processing of arsenic containing ores is a problem due to the emission of toxic gases (Filippou et al. 2007). Biohydrometallurgy is widely used to process gold bearing concentrates, and may also be used to extract non-ferrous metals arsenic-containing concentrates (Neale et al. 2017). The goal of the present work was to study copper bioleaching from arsenic-containing minerals and chalcopyrite at different temperatures and in $\mathrm{NaCl}$ presence.

\section{Methods and Approaches}

Chalcopyrite $\left(\mathrm{CuFeS}_{2}\right)$, enargite $\left(\mathrm{Cu}_{3} \mathrm{AsS}_{4}\right)$, and tennantite $\left(\mathrm{Cu}_{12} \mathrm{As}_{4} \mathrm{~S}_{13}\right)$ as well as mixed culture of acidophilic microorganisms oxidizing ferrous iron and sulfur compounds were subjects of the study. The experiments were carried out in flasks with $100 \mathrm{ml}$ of nutrient medium supplemented and $2 \mathrm{~g}$ of milled minerals $\left(\mathrm{P}_{100} 75 \mu \mathrm{M}\right)$ on a rotary shaker at temperatures from $40{ }^{\circ} \mathrm{C}$ to $60{ }^{\circ} \mathrm{C}$ for 30 days. In one variant of the experiment, nutrient medium was supplemented with100 $\mathrm{mm} \mathrm{NaCl}$.

\section{Results and Discussion}

The results of the experiments (rates of copper extraction) are shown in Table 1. 
Table 1. Rate of copper extraction from the minerals for 30 days (\%)

\begin{tabular}{l|l|l|l}
\hline $\begin{array}{l}\text { Variant of the } \\
\text { experiment }\end{array}$ & $\begin{array}{l}\text { Chalcopyrite } \\
\left(\mathrm{CuFeS}_{2}\right)\end{array}$ & $\begin{array}{l}\text { Enargite } \\
\left(\mathrm{Cu}_{3} \mathrm{AsS}_{4}\right)\end{array}$ & $\begin{array}{l}\text { Tennantite } \\
\left(\mathrm{Cu}_{12} \mathrm{As}_{4} \mathrm{~S}_{13}\right)\end{array}$ \\
\hline $40{ }^{\circ} \mathrm{C}$ & $14.33 \pm 0.08$ & $8.18 \pm 0.65$ & $15.33 \pm 0.24$ \\
\hline $45^{\circ} \mathrm{C}$ & $17.84 \pm 1.69$ & $12.89 \pm 1.79$ & $26.16 \pm 1.33$ \\
\hline $50{ }^{\circ} \mathrm{C}$ & $25.29 \pm 4.15$ & $14.04 \pm 0.95$ & $18.43 \pm 0.84$ \\
\hline $50^{\circ} \mathrm{C}, 100 \mathrm{NaCl}$ & $33.25 \pm 0.12$ & $5.91 \pm 1.09$ & $13.04 \pm 0.03$ \\
\hline $55^{\circ} \mathrm{C}$ & $26.75 \pm 1.57$ & $14.39 \pm 0.01$ & $14.84 \pm 0.01$ \\
\hline $60^{\circ} \mathrm{C}$ & $17.32 \pm 1.01$ & $5.86 \pm 2.18$ & $12.83 \pm 0.17$ \\
\hline
\end{tabular}

We showed that the rate of copper extraction from all minerals depended on temperature and was low at $40{ }^{\circ} \mathrm{C}$. Extraction rate at $60{ }^{\circ} \mathrm{C}$ was also low as this temperature might inhibit microbial activity. Addition of $\mathrm{NaCl}$ increased rate of copper extraction from chalcopyrite that was a well known phenomenon. At the same time, $\mathrm{NaCl}$ addition led to the decrease in copper extraction rate.

\section{Conclusions}

The results obtained suggest that the efficiency of copper sulfide minerals depended on temperature, while $\mathrm{NaCl}$ addition did not allowed increasing the rate of copper bioleaching from arsenic-containing minerals in contrast to chalcopyrite. This fact should be taken into consideration when planning laboratory scale trials on bioleaching of copper sulfide concentrates.

Acknowledgements. The work was supported by the President Grant of the Russian Federation, grant No. MK-6639.2018.8.

\section{References}

Filippou D, St-Germain P, Grammatikopoulos T (2007) Recovery of metal values from copper arsenic minerals and other related resources. Miner Process Extr Metall Rev 28(4):247-298

Neale J, Seppälä J, Laukka A, van Aswegen P, Barnett S, Gericke M (2017) The MONDO minerals nickel sulfide bioleach project: from test work to early plant operation. Solid State Phenom 262:28-32 
Open Access This chapter is licensed under the terms of the Creative Commons Attribution 4.0 International License (http://creativecommons.org/licenses/by/4.0/), which permits use, sharing, adaptation, distribution and reproduction in any medium or format, as long as you give appropriate credit to the original author(s) and the source, provide a link to the Creative Commons license and indicate if changes were made.

The images or other third party material in this chapter are included in the chapter's Creative Commons license, unless indicated otherwise in a credit line to the material. If material is not included in the chapter's Creative Commons license and your intended use is not permitted by statutory regulation or exceeds the permitted use, you will need to obtain permission directly from the copyright holder.

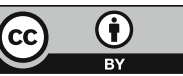

